\title{
REARING OF THE LEOPARD MOTH, ZEUZERA PYRINA $L$. (LEPIDOPTERA: COSSIDAE) ON CASUARINA TREES, CASUARINA SP.: CASUARINACEAE IN EGYPT
}

\author{
R. M. Abdel Moaty \\ Plant Protection Research Institute, Agric. Res. Center, MOA, Dokki, Giza, Egypt.
}

Received: Oct. 30,2018

Accepted: Nov. 17,2018

\begin{abstract}
Casuarina trees is one of the most important wood furniture as well as the most windbreak in fruit orchards In Egypt. Zeuzera pyrina (Lepidoptera: Cossidae) is a destructive polyphagous pest to fruit, wood and ornamental trees. Larvae of. Z. pyrina were reared on casuarina branches in the laboratory. Number of larvae and pupae completed their development, percentage of pupation, larval and pupal durations, rate of moth emergence, mating, oviposition, longevity, incubation period and percentage of hatchability were studied in casuarina branches under laboratory conditions. The preoviposition period was only one day, the incubation period averaged 11.7 (10 - 16 days), and the pupal duration averaged 16.2 (14 - 17) days. Approximated total life cycles were 281.5 (244 - 298) days when reared on casuarina. The relatively long period of larval period of infestation ranged between 219 - 264 days with an average of 252.6 days. It could be concluded that, further studies must be done on the control of this pest to eliminate its damage on casuarina trees and the neighboring fruit orchards.
\end{abstract}

Key words: wood leopard moth, biology, hosts , life cycle , Zeuzera spp

\section{INTRODUCTION}

Casuarina trees (Casuarina sp.) (Casuarinaceae) is widely spread all over the Egyptian farms especially in all the newly reclaimed lands. Wood and ornamental trees are used also as wind breaks especially around fruit plantations. Zeuzera pyrina L. (Lepidoptera: Cossidae) is a serious polyphagous pest attacking several wood trees such as poplar and casuarina, fruit trees especially apple, pear, pomegranate, olive, fig, pecan, as well as some ornamental tree (Tadros and AbdAllah, 1987). Larvae bore destructive tunnels inside the tree branches and stems, consume large amount of wood, causing weakness, reducing the wood production, and finally death of trees. Infested casuarina trees are renewable source of $Z$. pyrina infestation to fruit and other wood trees in fruit orchards Azmy et.al. (1978).

Zeuzera pyrina was reared on several fruit tree branches such as olive
(Mokhtar,1978; Tadros, and Abd-Allah, 1987), Tadros, et al., (2003) on apple, pear, pomegranate, olive , Abdel-moaty, et al., (2009) on fig. (El-Sherif, et al. (1985) in apple, pear and olive, Mesbah, et al. (1994) in apple, pomegranate, pear, guava, pecan and olive and Tadros, et al. (2007) on pear.

Morever Abdel-moaty (2001) in Egypt and Moore and Navon (1966), Navon (1977) in Israel, Tsourgianni (1995) in Greece and Garcia and Haro (1986) in Spain reared $Z$. pyrina on artificial medium diet.

Mansour and Tadros (2001) monitored $Z$. pyrina on the wood of poplar trees during three successive years (2003, 2004 and 2005) in two ecologically different localities the old valley lands and new reclaimed lands.

The rearing of phytophagous insects is advantageous in studying insect pathogens, plant resistant factors, effect of insecticides and study of radiation on 
fertility and growth. In an attempt to contribute to such a gap in the knowledge, the present biological studies are aimed. The broad objective of investigation is to add new information that may help in planning of rather effective "Integrated Control Programs" for the management of $Z$. pyrina in casuarina trees.

\section{MATERIALS AND METHODS}

During winter (2016 / 2017), casuarina branches infested with $Z$. pyrina were transferred from the newly reclaimed lands in Noubaria district, Behera governorate to the laboratory at Plant Protection Research Institute, Dokki, Giza. Infested branches were dissected and the pre-pupae and pupae were collected while older larvae were left in their tunnels inside the infested branches until pupation. Pupae were wrapped in toilet paper, fixed in place, kept in small specimen tubes $(1 \times 4 \mathrm{~cm})$ and placed into another larger ones $(2 \times 7.5 \mathrm{~cm})$ lined with blotting paper to give moths a grasp when struggling during their emergence from pupal exuvia. Then, pupae were kept in an incubator at $25{ }^{\circ} \mathrm{C}$ and $55 \%$ relative humidity (Mokhtar, 1978).

Soon, after emergence, moths were released in pairs (one male and one female) in small cylindrical wire gauze cage (10 cm diameter and $15 \mathrm{~cm}$ high) lined with rough paper to provide a suitable site for egg-laying, top and bottom were covered with Petri dishes. Eggs were daily collected and kept in an incubator at $25^{\circ} \mathrm{C}$ and $55 \%$ relative humidity until hatching.

After hatching, larvae were introduced into fresh cuttings of casuarina trees (about $1 \mathrm{~cm}$ diameter and $20 \mathrm{~cm}$ length) sterilized with $0.25 \%$ formaldehyde tap water, soaked from the two ends with wax and kept in glass jar, (5 liters) containing moistened sand. Enclosed larvae were shifted into new thicker fresh cuttings as needed (about 3 week intervals) until completed their development (in prepupal stage). The larva, pupa, adult (mating, oviposition and longevity), eggs stage and the total life cycle were studied under mean laboratory conditions of $26.2 \pm 1{ }^{\circ} \mathrm{C}$ and $60 \pm 2 \%$ R.H.

Analysis of variance (F test), T-test, and Duncan Multiple Range Test (SAS) methods were used according to Snedecor and Cochran (1990).

\section{RESULTS AND DISCUSION}

During the period from May, 2017 until July, 2018; $Z$. Pyrina was reared on its natural host of casuarina branches under mean laboratory conditions (26.2 $\pm 1{ }^{\circ} \mathrm{C}$ and $60 \pm 2 \%$ R.H.).

\section{Larval and pupal stages:}

Newly hatched larvae started boring their tunnels under the bark. Data in Table (1) showed that $31 \%$ of larvae could complete their development and started pupation in casuarina branches. The same Table also showed that the larval duration ranged 219-264 with an average of $252.6 \pm 6.31$ days) when reared on casuarina branches.

Out of 31 larvae that completed their development,26 pupae completed their developments to adults and emerged, recording $83.9 \%$ success of pupal development (recovery).(Table,1).

The pupal duration (Table 1) was recorded from larvae reared on casuarina branches ranged 14 - 17 days, with an average of $16.2 \pm 1.28$ days to reach adult stage.

\section{Adult stage:}

The rate of moth emergence from pupae reared on casuarina branches was $83.9 \%$ (Table 1).

Coitus lasted 17-39 (mean of 26.8 \pm 9.42) minutes for moths reared on casuarina branches (Table 2). 
Table 1: Effect of casuarina natural host plant on larval and pupal durations of $Z$. pyrina reared under laboratory conditions.

\begin{tabular}{|c|c|c|}
\hline \multicolumn{2}{|l|}{ No. of larvae used } & 100 \\
\hline \multicolumn{2}{|l|}{ No. of larvae pupated } & 31 \\
\hline \multicolumn{2}{|l|}{$\%$ pupation } & 31 \\
\hline \multirow{2}{*}{ Larval duration (in days) } & Average & $252.6 \pm 6.31$ \\
\hline & Range & $219-264$ \\
\hline \multicolumn{2}{|c|}{ No.of pupae completed their development } & 26 \\
\hline \multirow{2}{*}{ Pupal duration (in days) } & Average & $16.2 \pm 1.28$ \\
\hline & Range & $14-17$ \\
\hline \multicolumn{2}{|l|}{$\%$ moth emergence } & 83.9 \\
\hline
\end{tabular}

Means with the same letter are not significantly different $(P<0.05)$ using Duncan's Multiple Range Test (SAS).

Table (2): Mating, oviposition, longevity periods and number of eggs laid by female $Z$. pyrina reared on casuarina branches under mean laboratory conditions.

\begin{tabular}{|c|c|c|}
\hline \multicolumn{2}{|c|}{ Coitus (in minutes) } & $26.8 \pm 9.42(17-39)$ \\
\hline \multicolumn{2}{|c|}{ Pre-oviposition period (in days) } & 1 \\
\hline \multicolumn{2}{|c|}{ Oviposition period (in days) } & $6.1(5-8)$ \\
\hline \multicolumn{2}{|c|}{ Post-oviposition period (in days) } & $0.6(0-1)$ \\
\hline \multicolumn{2}{|c|}{ No. of laid eggs } & $852(655$ - 1109) \\
\hline \multicolumn{2}{|c|}{ No. of eggs in ovaries } & $41(22-116)$ \\
\hline \multicolumn{2}{|l|}{ Fecundity } & 893 \\
\hline \multicolumn{2}{|c|}{ Incubation period (in days) } & $11.7(10-16)$ \\
\hline \multicolumn{2}{|c|}{ Hatchability (\%) } & $92 \%(80-97 \%)$ \\
\hline \multirow{2}{*}{$\begin{array}{l}\text { Longevity } \\
\text { (in days) }\end{array}$} & Female & $7.3(6-8)$ \\
\hline & Male & $6.9(5-9)$ \\
\hline
\end{tabular}


Eggs were laid in small chains of 5-14 eggs each or in masses of $33-118$ eggs. Fertile eggs were laid (pre-oviposition period) after mating mostly the next day.

Oviposition period lasted 5 to 8 days with an average of 6.1 days. Females died at the last day of oviposition or one day after oviposition period (post-oviposition period).

Fertile females reared on casuarina branches laid 655 - 1109 eggs with an average 852 eggs. The number of eggs remained in the ovaries after death of females were $41(22$ - 116) eggs. Thus, the fecundity approximated 893 eggs. The respective pre-oviposition period was 1 days, while the oviposition period was $6.1(5-8)$ days. The post-oviposition period was $0.6(0-1)$ days (Table 2).

Females $Z$. pyrina reared on casuarina branches lived 6-8 days with an average of 7.3 days. The respective longevity of males lived for 6.9 (5 - 9) days (Table 2).

\section{The egg stage:}

Table (3) indicated that under mean laboratory conditions of $29 \pm 1{ }^{\circ} \mathrm{C}$ and 56 \pm 1 R.H.), the incubation period reached $11.7 \pm 0.8(10-16)$ days for laid eggs by females reared on natural hosts of casuarina branches. Under the same temperature and R.H., the respective percentage hatchability was $92(80$ 97\%).

\section{Approximated life cycle:}

Table (3) approximated the life cycle of $Z$. pyrina reared on its natural host of casuarina branches under mean laboratory conditions of $26.9 \pm 1{ }^{\circ} \mathrm{C}$ and $61 \pm 1 \%$ R.H. The respective durations of total life cycle were 281.5 (244 - 298) days.

\section{Discussion:}

Rearing larvae of $Z$. pyrina on alive tissues is very difficult. Rearing $Z$. pyrina on natural host (casuarina branches) was carried out for the first time in this research. In Egypt results of rearing $Z$. pyrina on casuarina branches was almost disagreed with Mokhtar (1978) reared $Z$. pyrina on apple branches and recorded 270 - 317 days with an average of 298.6 days for larval duration. He further recorded 9 - 24 days for incubation period, 16 - 34 days for pupal duration, 4 - 15 days for adult longevity and 298 351 (average 330.1) days for the total life cycle. Moreover, Tadros, et al., (2003) reared $Z$. pyrina on apple, pear, pomegranate and olive branches and recorded respective total life cycles of $336.7,334.9,328.8$ and 377.4 , respectively ( range, 318 - 398 days) . In Spain Garcia and Haro (1986) reported $10-11$ months for larval duration of $Z$. pyrina.

Table (3): The approximated life cycle of $Z$. pyrina reared on casuarina branches under mean laboratory conditions

\begin{tabular}{|l|c|}
\hline Stages & Duration (in days) \\
\hline Larva & $252.6(219-264)$ \\
\hline Pupa & $16.2(14-17)$ \\
\hline Pre- oviposition & 1 \\
\hline Egg & $11.7 \pm 0.8(10-16)$ \\
\hline Total life cycle & $281.5(244-298)$ \\
\hline
\end{tabular}




\section{REFERENCES}

Abdel-moaty, R.M. (2001). Artificial medium diets and some alternative means of control of some Lepidopterous fruit tree borers .M.Sc. Thesis ,Fac. of Science, Cairo Univ.,Egypt.

Abdel-Moaty, R.M., M.M.A. El-Assal, I. A. Abdel-Hamid and A. W. Tadros (2009). Biological characteristics of Zeuzera pyrina L. (Lepidoptera: Cossidae) on fig in Egypt, Egypt. J. of Appl. Sci., 24 (6B): 730-738.

Azmy, N. M., G. El-Saadany and H. Helal (1978). Population dynamics of certain wood borers in Giza. Res. Bull., AinShams Univ., (827): 12.

El-Sherif, S.I., A.W. Tadros, F.M.L. Afifi and F.F. Abd-Allah (1985). Monitoring Zeuzera pyrina L. population in apple, pear and olive orchards. Bull. Fac. Agric., Univ. of Cairo, Egypt, 36 (2): 1293-1304.

Garcia, D. P. and A. Haro (1986). Laboratory culture of $Z$. pyrina on artificial diet. Boletin de Sanidad Vegetal Plags, 12 (2): 281-289.

Mansour, A. and A.W. Tadros (2001). Monitoring Zeuzera pyrina on poplar trees in Egypt. Egypt. J. Agric. Rec., accepted 2000.

Mesbah, H.A., A. W. Tadros and W.A. Shehata (1994). Seasonal fluctuation in Zeuzera pyrina population on apple, pomegranate, pear, guava, pecan and olive trees at Alexandria Governorate. Egypt. J. Agric. Res., 72 (1): 117-128.
Mokhtar, A. (1978). Studies on the leopard moth, Zeuzera pyrina, L. and its control. M. Sc. Thesis, Facutly of Agriculture, Cairo University, Egypt.

Moore, I. and A. Navon (1966). The rearing and some bionomics of the leopard moth $Z$. pyrina $L$. on an artificial medium. Entomophaga, 11: 285-286.

Navon, A. (1977). Rearing the leopard moth Z. pyrina L. on an improved diet. Phytoparasitica, 5 (1): 38-40.

Snedecor, W. and A. Cochran (1990). Statistical methods. The Iwa state Univ., press Ames. Iwa, USA.

Tadros, A.W. and F.F. Abd-Allah (1987). Studies on the biology of the leopard moth, Zeuzera pyrina L. (Lepidoptera: Cossidae) on olive trees in Egypt. Zagazig J. Agric. Res., Zagazig, Egypt, accepted January 1987.

Tadros, A.W., A. M. Abdel-Rahman and R.M. Abdel-Moaty (2003). Rearing Fruit Tree Borers on Natural Hosts and Artificial Medium Diet: (1) Zeuzera pyrina L. (Lep: Cossidae). Egypt. J. Agric. Res., 81 (4): 1535-1548.

Tadros, A.W., R. G. Abou El-Ela and M.M. Abdel-Azim (2007). Prediction of Zeuzera pyrina moths' activity based on pheromone trapping and degreeday accumulations in pear orchards in Egypt. Egypt. J. Agric. Res., Egypt, 85 (4): 1739-1752.

Tsourgianni, A. (1995). Rearing of $Z$. pyrina L. on artificial medium. Annales de L'Institut. Phytopathogique Benaki., 14 (2): 111-115. 


\section{تربية حفار ساق التفاح Zeuzera pyrina (رتبة حرشفية الأجنحة: عائلة كوسيدي) علي أشجار الكازورينا (الفصيلة الكازورينية) في مصر

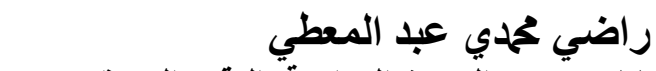 \\ معهد بحوث وقاية النباتات ، مركز التبحوث الزراعية، الدقي، الجيزة ، مصر}

الملخص العربي

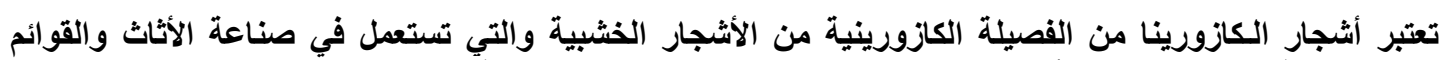

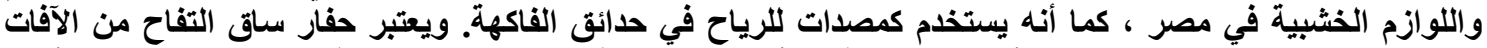

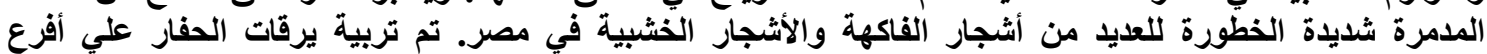

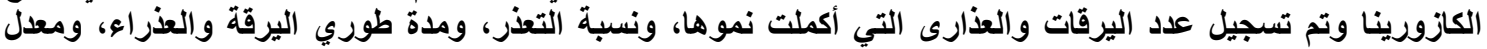

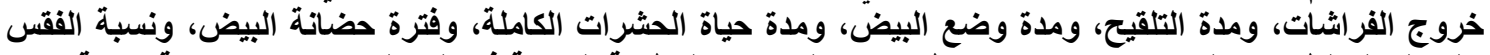

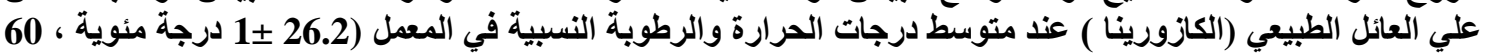

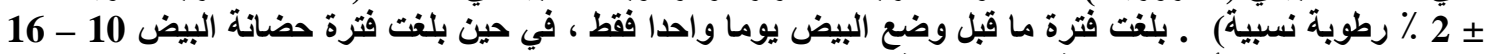

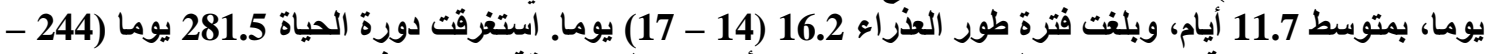

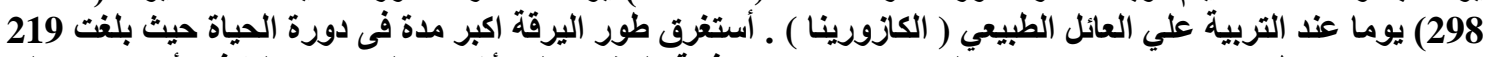

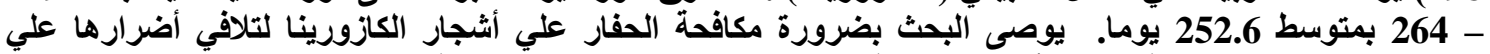

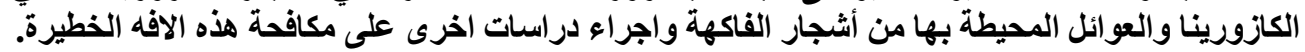

سماء السبادة المحكمين

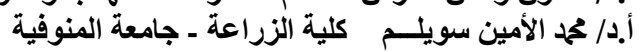


Menoufia J. Plant Prot., Vol. 4 February (2019): 1 - 6 